\title{
Synthesis of Climate Change Policy in Judicial, Executive, and Legislative Branches of US Government
}

\author{
Robert Brinkmann, Hofstra University, and Sandra Jo Garren, University of \\ South Florida
}

\section{Introduction}

Developing a comprehensive global warming and greenhouse gas policy has been difficult for the USA. While many other developed countries have implemented greenhouse gas initiatives, the USA became mired in the debate over the actual existence of global warming (McCright \& Dunlap 2003), the prudence of developing policy in the perceived lack of scientific information in support of global warming (Leiserowitz 2006), and the ways to go about reducing greenhouse gas emissions (McCarl \& Schnieder 2000; Rose \& Oladosu 2002). Indeed, while global warming was largely accepted by the scientific community by the early 1990s (IPCC 1992) throughout much of the Clinton and George W. Bush Administrations (IPCC 1995, 2001; IPCC 2007a, 2007b), no serious efforts to develop national greenhouse gas policies emerged. Several US leaders, including leaders in the executive and legislative branches of the government, doubted the existence of global warming and used evidence outside mainstream scientific inquiry to justify their position (Armitage 2005). Thus, the approach taken by the USA, until the election of President Obama, was largely one of debate with little policy development.

During this period, the absence of leadership at the national level led to a number of innovative initiatives by individuals, state and local governments, non-profit 
organizations, and private businesses. For example, Governor Schwarzenegger supported strong controls of emissions in California (Cayan et al. 2008), the US Council of Mayors developed goals for greenhouse gas reductions in cities (Schreurs 2008), the US Green Building Council began enhancing procedures for certifying green homes (Yudelson \& Fedrizzi 2008), the American college and university presidents developed strategies for reducing the impact on their campuses (Rowe 2007), the Chicago Climate Exchange (CCX) organized a mechanism for carbon trading (Labatt \& White 2007), Walmart developed aggressive green business practices (Freidman 2005), and businesses participated in voluntary greenhouse gas reporting and reduction programs (for example, the US EPA's Climate Leaders Program and the US DOE's Voluntary Reporting of Greenhouse Gases Program) and made a legally binding emission reduction commitment in the CCX (Carpenter 2001). However, while each of these actions is important for a number of reasons, none of them has the impact of an allencompassing national policy on greenhouse gas emissions. Therefore, much of what developed in recent years through local governments, non-profits, and businesses did not have a major impact on overall greenhouse gas outputs at the national scale.

Within this context, there have been several court challenges to the US government inaction as well as lawsuits against state governments and private organizations and individuals. These lawsuits have focused on a variety of policies including statutory issues such as The Clean Air Act, challenges to individual projects, state vehicle emissions standards, and common law claims. Although only a handful of these cases have been successful, they have resulted in a variety of interesting outcomes that have a direct impact on US greenhouse gas policy. At the same time, the US EPA, under the direction of the Obama administration, recently took significant actions to regulate greenhouse gases under the Clean Air Act, and the US Congress developed legislation that would have had far-reaching impacts for the future of greenhouse gas policy.

This paper reviews and synthesizes actions taken in the three branches of government, including some of the key national lawsuits that have impacted current US policy; it assesses pertinent actions to regulate greenhouse gases from the current presidential administration and the US EPA; and it summarizes the current congressional stalemate by reviewing the proposed climate legislation that passed the House of Representatives and was considered in the Senate prior to the 2010 elections. The paper adds to the 
current literature in that it summarizes key actions taken within the national policy framework and synthesizes climate policy options within the US government system.

\section{Greenhouse gas litigation (judicial branch)}

Many cases have been brought before the courts that attempted to address problems associated with greenhouse gas litigation (Gerrard 2007). They can be divided into categories of law: federal statutory law; challenges to individual projects using federal and state statutory law; vehicle emissions standards; common law claims with injunctive relief; and common law claims with financial relief (Arnold \& Porter LLP 2011). Each category will be discussed briefly to highlight the major cases and their outcome.

\section{Federal statutory law}

Lawsuits have been brought forward that utilize the provisions of The Clean Air Act, the Clean Water Act, the Global Change Research Act, the Alternative Motor Fuels Act, the Endangered Species Act, and the Energy Policy Act to test current practices of the US government actions within the courts. Perhaps the most tested aspect of federal statutory law is the failure of government to regulate greenhouse gases. Many of the proceedings have sought to compel the government to use its statutory power to reduce or prevent injury from climate change caused by greenhouse gas emissions. Bringing such a claim to court is difficult in that the litigant must demonstrate legal standing to bring the case (that is, they must experience direct damages) and they must be able to demonstrate the link between inaction by the government and resultant damage.

The most successful of these cases is Massachusetts et al. v. US EPA et al. (United States Supreme Court 2006). In this case, the state of Massachusetts and other petitioners brought forward a lawsuit to require the US EPA to regulate greenhouse gases from tailpipe emissions to eliminate future damages. The case challenged US EPA's contention that it did not have congressional mandate to regulate greenhouse gases. In addition, the US EPA's stated policy was that even if it was decided that they had regulatory authority over greenhouse gas regulation, they would opt not to regulate the gases due to the unique nature of the pollution. They also stated that the scientific link between greenhouse gases and global warming was not clear. Eventually, the case was heard in the US Supreme Court where it was decided by a 5 to 4 majority that US EPA was required to regulate greenhouse gases. 
There were several key points to this case. First, the court decided that Massachusetts and the other petitioners have standing to bring the case. This has proven difficult (as discussed further in the analysis of Kivalina v Exxon et al. below) in greenhouse gas cases. In this case, the State of Massachusetts was held to have standing due to direct or imminent threats to its territory due to the impact of global warming. Another important aspect of the case is the court's recognition that global warming brought on by greenhouse gases is a real and recognized threat to property. This countered the US EPA, which at the time stated that the links between greenhouse gases and the effects of global warming were not clear. In addition, the court also asserted that US EPA's failure to regulate greenhouse gases contributed to the injury experienced by the State of Massachusetts and that the US EPA had a duty to attempt to slow or reduce greenhouse gases by regulating emissions.

The result of the Supreme Court decision is that the US EPA must consider greenhouse gases as regulated pollutants. This decision, prior to the 2008 Presidential election, caused the US EPA to develop a policy in the midst of significant political change in which the new Obama administration was likely to work toward a comprehensive national greenhouse gas policy. In response to this ruling, the US EPA has initiated a flurry of regulatory initiatives and rulemaking activities to regulate greenhouse gas emissions from not only tailpipes, but from other sources of greenhouse gas emissions (see below for more details). In addition to the regulation, the US EPA signed the Endangerment Finding and Cause or Contribute Finding for Greenhouse Gases under the Clean Air Act in December 2009, widely known as the Greenhouse Gas Endangerment Finding. In these findings, the US EPA concluded that six greenhouse gases: carbon dioxide, methane, nitrous oxide, hydrofluorocarbons, perfluorocarbons, and sulfur hexafluoride threaten the public health and welfare. In addition, the US EPA noted that carbon dioxide, methane, nitrous oxide and hydrofluorocarbons emitted from vehicle exhaust contribute to climate change and must be regulated. The more conservative congress elected in 2010 has made attempts to reverse the US EPA's actions via legislation, and ten Petitions for Reconsideration, including petitions from the Chamber of Commerce and the State of Texas, were submitted to the US EPA for evaluation. To date, these attempts and petitions have failed and the US EPA has held steadfast in upholding the findings. 
The Endangered Species Act is another law that was tested through litigation to attempt to force the federal government to address global climate change. Perhaps the most well-known case involved the Center for Biological Diversity’s case against the Department of the Interior and other defendants for a lack of protection for the polar bear (United States District Court for the Northern District of California 2007a, 2007b). Polar areas are at great risk from global warming as subtle changes in temperature can melt sea ice and greatly alter ocean conditions. The polar bear, which is partly dependent on sea ice as a habitat, is particularly vulnerable to global climate change. In 2007, the Center for Biological Diversity sued the federal government to take action. While the Bush and Obama administrations have not supported the use of the Endangered Species Act to address climate change, the Bush administration did settle the lawsuit by designating 200,000 acres of land, sea, and ice as critical habitat for the polar bears.

Another Center for Biological Diversity groundbreaking lawsuit associated with global warming involved the use of the Clean Water Act in trying to regulate ocean acidification off the shores of the United States (Craig 2009). A substantial proportion of the carbon dioxide emitted into the atmosphere from human activities is absorbed in the oceans and this is causing a process known as ocean acidification throughout the world's oceans (Hoegh-Guldberg et al. 2007). Among other things, ocean acidification leads to decreased shell and skeleton production by many species of marine life which depend upon calcium carbonate (Hays, Richardson, \& Robinson 2005). In 2007, the Center for Biological Diversity commenced a lawsuit contending that the oceans off a portion of Washington State were being impaired due to ocean acidification. They noted that the US EPA did not list the waters impacted by the $\mathrm{pH}$ change as impaired in their listing of impaired water bodies in Washington. Designated impaired water bodies require particular action. Thus, the Center for Biological Diversity contended that the US EPA's decision not to list the water bodies had a direct negative impact on the nearshore water quality. Indeed, the lawsuit notes that $\mathrm{pH}$ declined 0.2 points on the $\mathrm{pH}$ scale since 2000, which violates Washington's water quality standards. Not surprisingly, there is great concern for the future of Washington's fisheries. In early 2009, the US EPA wrote to the Center for Biological Diversity stating that they would initiate a comprehensive examination of ocean acidification in order to arrive at a better assessment of water quality attainment in marine waters (United States Environmental 
Protection Agency 2009). To that end, the US EPA sought has sought data, public comment, and other information in an effort to understand ocean acidification better (Federal Register 2009). The public comment period ended in May 2010 and a memorandum was issued in November 2010, which requires states to list waters as impaired if there is evidence for $\mathrm{pH}$ decreases beginning in 2012 (US Environmental Protection Agency 2010).

Another area of litigation has gone in the direction of requiring the federal government to release documents and follow existing law to assess greenhouse gas impacts. For example, the Global Change Research Act required the US government to develop regular reports on the current state of greenhouse gas research in the United States. In addition, the reports were to assess implications for the environment in order to guide national and world climate policy. The government did not complete the report in a timely fashion under the G. W. Bush Administration. Thus, the government was taken to court and compelled to complete the work as per a court order (United States District Court for the Northern District of California 2007a). Likewise, the Freedom of Information Act was used in a successful lawsuit brought forward by the Center for Biological Diversity and Others against the US Office of Management and Budget $(\mathrm{OMB})$ that asked the courts to require the $\mathrm{OMB}$ to release documents associated with the development of fuel economy standards for US vehicles without a fee (United States District Court for the Northern District of California 2008).

In a similar lawsuit using the US Energy Policy Act of 1992, the Center for Biological Diversity once again sued the Federal Government for not complying with the reporting requirement of the US Energy Policy Act (United States Department of Energy Energy Efficiency \& Renewable Energy 2010). Because the US Government was not publishing the required reports, it was difficult to ascertain whether it was complying with the requirements of the Act, which, among other things required the government to develop a fleet of alternative fuel vehicles. The Center for Biological Diversity largely won the case and the government was required to comply with the strict reporting requirements. While this may seem like a small victory, the suite of lawsuits discussed here demonstrated the lack of transparency in government. Indeed, there was a perception that the federal government was hostile to the issue of climate change and preferred to work on other areas of environmental policy. In the face of limited or no 
progress in implementing national policies to limit greenhouse gas emissions, environmental non-governmental organizations have felt obliged to pursue numerous cases concerning document access and compliance with reporting requirements.

\section{Challenges to individual projects}

Another form of greenhouse gas litigation is in the form of challenges to individual projects. Most of these cases have challenged the construction of coal-fired power plants. These cases are challenging for applicants in that they must demonstrate direct injury to an individual or property owner due to global warming, and they must prove that the power plant would be responsible, in part, for climate change. The political context for these lawsuits is often brought into question by respondents. Defendants have argued that within the present political situation, when there is no guidance from the US government on greenhouse gas issues, they should not be regulated by the courts. Indeed, in one decision handed down by the Supreme Court of South Dakota upholding the right of the Otter Tail Power Company to proceed with construction of a new power plant, the court noted that 'As members of the judiciary, we refrain from settling policy questions more properly left for the Governor, the Legislature, and Congress. No matter how grave our concerns on global warming, we cannot allow personal views to impair our role under the Constitution' (Supreme Court of South Dakota 2008). Nevertheless, several lawsuits have impacted the nature of power plant construction in various locations around the country.

Perhaps the most interesting of several power plant lawsuits and challenges occurred in Georgia where Longleaf Energy Associates wished to construct a 1,200 megawatt coalburning power plant in Early County, Georgia. Challenging the construction in the Superior Court of Fulton County, Georgia, the Friends of the Chattahoochee and the Sierra Club sued Longleaf Energy Associates for failure to conduct appropriate analysis and modeling on air pollution (Superior Court of Fulton County 2008). One of their key arguments was that they did not conduct any analysis of carbon dioxide emissions. They claimed that after the Supreme Court Decision of Massachusetts v. US EPA requiring the US EPA to regulate carbon dioxide, those constructing a power plant must conduct a best available control technology (BACT) analysis to determine how best to reduce carbon dioxide emissions from the power plant. Longleaf Energy argued that the US EPA had not yet published guidelines and that they should not be held responsible for 
BACT analysis since there was not yet any clear federal guidance on the issue. However, the court sided with the Friends of the Chattahoochee and the Sierra Club in noting that the Clean Air Act specifically defines an air pollutant as any pollutant subject to regulation. The court argued that since the publication of Massachusetts v. US EPA carbon dioxide was defined as a pollutant subject to regulation and thus must be addressed in any BACT analysis. Thus, the court ruled that the project could not proceed until a BACT analysis that included carbon dioxide was completed. While many cases challenging the construction of power plants have been dismissed due to the lack of regulatory guidelines on greenhouse gas emissions, this case brought forward the possibility of greater regulation of carbon dioxide at sources as a result of Massachusetts v. US EPA.

A case from 2006 foreshadowed US EPA v. Massachusetts and the Longleaf Power Plant case. Owens Corning Corporation, while constructing a polystyrene foam insulation facility in Gresham, Oregon, was challenged by the Northwest Environmental Defense Center, the Oregon Center for Environmental Health, and the Sierra Club (United States District Court for the District of Oregon 2006). The plaintiffs argued that the site was not permitted correctly since it was going to emit more than 100 tons per year of a regulated pollutant. In addition, they argued that the gases emitted, particularly 1-chloro-1, 1-difluoroethane (HCFC-142b), were greenhouse gases and ozone depleting substances that could prove harmful to residents in the community in a variety of ways. Owens Corning argued, in part, to dismiss the case on the grounds that the plaintiffs did not have standing and that there was no injury caused by global warming to the litigants. Interestingly, the court noted that even though greenhouse gases from various sources are mixed in the atmosphere, local sources do contribute to local impacts. Thus, the emissions of one particular plant, combined with all other emissions around the world can impact local conditions such as sea level or snow pack. Therefore, the individual source should be regulated to reduce local impacts, even though there are multiple sources.

\section{State vehicle emissions standards}

Another branch of greenhouse gas law focuses on controlling emissions standards of vehicles. In recent years, there has been much focus on federal corporate average fuel emissions (CAFE) standards for auto emission requirements for auto manufacturers 
(Austin \& Dinan 2005). The US EPA is the organization that sets CAFE standards. However, because California was involved with fuel economy standards prior to the passage of the Clean Air Act, the state was given special status and can apply for waivers to the US CAFE standards for stricter rules. Such waivers were granted many times since 1968. However, in 2005 and 2006, the California Air Resources Board sought permission from US EPA to increase fuel efficiency once again. This time, in 2007, the request was denied and lawsuits followed.

Many US states are interested in tightening federal guidelines (Lutsey \& Sperling 2005). However, when California attempted to implement its new standards, several lawsuits were filed. In these lawsuits, various players in the automobile industry questioned California's right to develop CAFE standards. Manufacturers and dealers also argued that the development of multiple emissions standards would be a hardship on the US auto industry since multiple standards would require multiple designs and thus drive up the costs of production.

While the courts have been mixed in their reviews of this branch of law, for example, Central Valley Chrysler Jeep and others sued the California Air Resources Board over emissions standards (United States District Court for the Eastern District of California 2008), the Bush administration did not support California’s new guidelines. However, with new Presidents come new policy approaches. In 2009, President Obama supported California-like standards for different states, but required that they be managed by the US EPA and not the states. New flexible standards that allow trading was approved in 2009.Thus, the lawsuits had a distinct effect on the development of a new approach to manufacturing fuel-efficient cars. Yet, when the City of New York sought to require that all taxis be hybrid vehicles, the Metropolitan Taxicab Board of Trade sued on the grounds that the city did not have the right to set CAFE standards (Grynbaum 2011). The case ended up in the US Supreme Court that essentially confirmed that the Federal Government was the only organization that can set CAFE standards. Thus, New York City was not allowed to enact a hybrid-only rule for cabs.

\section{Common law claims with injunctive relief}

Another avenue for greenhouse gas litigation is the use of common law claims, in some cases involving a request for injunctive relief. Injunctive relief may be sought by a litigant in order to stop a person or organization from doing something that they 
perceive as harmful. In some environmental cases, injunctive relief has stopped emissions of a pollutant or caused the development of environmental policy. For example, in 2005, Connecticut and several other states sued American Electric Power and several other power companies in attempts to force greenhouse gas emission reductions from their power plants (United States Supreme Court for the Southern District of New York 2005). The plaintiffs asked the court to cap emissions from the power plant and to develop a schedule of reductions for emissions due to greenhouse gas pollution.

The nature of these types of cases makes it difficult for courts because they do not like to adjudicate cases that are political in nature. If there are large policy issues at stake, courts prefer that the issues be addressed at the legislative or executive branches of government. In the Connecticut v. American Power case, this is exactly what the court decided. The issue was too big for the courts to manage effectively and the case was won by the defendants in district court. Interestingly, the case was overturned at the Circuit Court in September of 2009 when the court ruled that the case was judiciable under the political question doctrine (The United States Court of Appeals for the Second Circuit 2005). This turnabout, similar to that provided by Comer et al. v. Murphy Oil USA et al (United States Court of Appeals for the Fifth Circuit 2009), provides opportunities for individuals and organizations to bring greenhouse gas emission nuisance claims forward in the court. In a similar case, Korsinsky v. the US EPA et al. (United States District Court for the Southern District of New York 2005), the plaintiff petitioned the court to require US EPA to reduce greenhouse gas emissions to address health threats from global warming. However, the court found that the plaintiff's injuries were not enough to grant him standing to bring this suit.

\section{Common law claims with financial relief}

One of the most controversial areas of greenhouse gas litigation has been the seeking of damages due to the result of greenhouse gas emissions. There is growing evidence that some communities have been deleteriously impacted due to global warming (Patz et al. 2005). According to an abundance of national and international law (Organization for Economic Co-Operation and Development 1992), a polluter is responsible for damages caused as a direct result of the pollution. However, greenhouse gas emissions and concomitant global warming are dispersed across the planet from multiple sources in all 
countries of the world. Thus, the challenge is to show the direct link between global warming and associated damages. Nevertheless, some cases have tested the courts to seek damage claims against producers of petroleum products. The line of reasoning for this argument is similar to that used in the tobacco lawsuits, which claimed that tobacco companies continued to produce a product that they knew was harmful to human health. Therefore, a key aspect in any lawsuit of this type is that the litigant must demonstrate that the petroleum companies knew of damages they were inflicting on the environment through the burning of their product.

Perhaps the best-known case that tested this area of law is Kivalina v Exxon et al. (United States District Court for the Northern District of California 2009). Kivalina was a small native Alaskan village that existed on a small spit of land offshore of Alaska. The community was a traditional fishing village with less than one hundred households. In the last decade, the ice surrounding the village began to disappear, leaving the shore susceptible to wave erosion, particularly during fall and spring storms when sea ice, which normally would be present, was absent. The village sued a number of petroleum producers and energy producing companies for the costs associated with moving the village, arguing that they were partly responsible for past and ongoing contributions to global warming and that the defendants were responsible for perpetuating a conspiracy to suppress the knowledge of a link between greenhouse gas emissions and global warming.

As noted, the lawsuit had several political hurdles, and it was dismissed by the United States District Court for the Northern District of California. The court decided this case on two grounds. First, the court argued that the case dealt with matters that have not been decided politically. The court concluded that the legislative and executive branches of government were the best avenues for developing policy on greenhouse gases. In addition, the court noted that everyone on the planet is in some way responsible for greenhouse gas emissions and that it is difficult to develop sound policy under such circumstances. In addition, the court ruled that the village did not have standing to bring the case since the pollution could not be 'fairly traceable' to the defendants. In other words, the court felt that there must be more direct proof that the emissions put out by the defendants had a direct link to the coastal erosion that caused the damage to the village. The court felt that the links were too weak to make the defendants responsible 
for the damages to Kivalina. The plaintiff in this case has appealed the decision. It seems apparent that the village was destroyed as a result of changing temperatures in the Arctic region. The question is whether the courts will assert a link between emissions and global warming and assign damage recovery. The implications of this type of lawsuit are significant. If won, it would set a precedent for financial recovery caused by greenhouse gas emissions and an onslaught of court cases would be filed that could potentially harm the energy industry and its linked economies.

\section{Presidential action and the US EPA (executive branch)}

As introduced in the previous section, the Supreme Court ruling from Massachusetts v. US EPA resulted in authorizing the US EPA to regulate greenhouse gas emissions from tailpipe emissions. While the case was decided in 2007, no change in policy occurred until recently. As already discussed, this inaction was mostly a function of a lack of leadership in former Presidential administrations. However, a shift occurred when Barrack Obama pledged in his Presidential campaign to 'fight climate change, invest in clean, renewable energy, and chart a new energy future’ (Organizing for America 2009).

To date, the President has made great strides in following through on his commitment. For example, in October 2009, the President issued an Executive Order to 'lead by example’ by committing all Federal agencies to set greenhouse gas reduction targets within 90 days as well as a number of other sustainability goals (Council on Environmental Quality 2009). Additionally, President Obama made several key appointments (for example, Steven Chu in the Department of Energy and Lisa Jackson in the US EPA) to agencies and has directed these agencies to take significant action to transition to clean energy and reduce greenhouse gas emissions (The Office of the President Elect 2008). Chu and Jackson have led their organizations to develop the President's agenda to move the country towards addressing climate change. The American Recovery and Reinvestment Act provided over US\$800 billion in stimulus funds, much of which was intended to facilitate the USA's transition towards clean energy while at the same time jump starting the economy. Additionally, the President signed a memorandum to improve energy efficiency of appliances. Lastly, the President signaled to Congress that he would sign into law legislation with significant greenhouse gas reduction targets of 17 percent of 2005 levels by 2017 and 83 percent by 2050 . 
The greenhouse gas reduction targets were announced just prior to the post-Kyoto meeting in Copenhagen in December 2009, which along with the House of Representative’s-passed climate bill the summer 2009 (see discussion below), showed some progress on federal climate change in the USA. However, since the climate bill had yet to pass the Senate prior to Copenhagen, the Obama administration was limited in becoming a powerful negotiator at the meetings (Samuelsohn 2009). Regardless, one outcome of the Copenhagen negotiations is that the USA, along with Brazil, China, India, and South Africa, signed the Copenhagen Accord (United Nations Framework Convention on Climate Change 2009). By signing the Accord, delegates pledged to emission target reductions, agreed that climate change is 'one of the greatest challenges of our time,' and concurred that deep cuts are needed to avert a dangerous increase in temperatures. It is unknown what the impact of the USA signing of the Copenhagen Accord will be since the Accord is non-binding and the USA's reduction targets have not been legislated through Congress. However, by signing the Accord, the President sent the message to the international community that the USA is serious about addressing climate change, and participation was thought to have improved the President's chances for swaying the Senate in passing climate policy (Samuelsohn 2009). In Durban, the USA reported progress towards the reduction target and highlighted two recent actions from the Obama administration (i.e., increase in the fuel economy standard and investments in clean energy technology through the stimulus bill) (Sheppard 2010).

Under the direction of Administrator Lisa Jackson and the backing of the Obama Administration, the US EPA has taken significant regulatory action to address climate change under the Clean Air Act (United States Environmental Protection Agency 2009). First, rulemaking to regulate emissions from stationary sources began by setting thresholds for greenhouse gas emissions and permitting requirements for new and existing industrial facilities (known as the Tailoring Rule). The ruling will cover approximately 70 percent of industrial facilities (i.e., electricity providers, refineries, and other high energy users). Second, the US EPA finalized a mandatory ruling whereby facilities in selected sectors that emit more than 25,000 metric tons of carbon dioxide equivalents $\left(\mathrm{mtCO}_{2} \mathrm{e}\right)$ must publicly monitor and report greenhouse gas emissions annually beginning in 2010. A carbon dioxide equivalent is a standardized term used to account for all non-carbon dioxide greenhouse gases in the reporting of 
emissions in a regulatory scheme. Non-carbon dioxide greenhouse gases are converted to equivalents by multiplying by its respective global warming potential (IPCC 2007a, 2007b). This ruling will cover about 85 percent of greenhouse gas emission sources. Third, a final ruling was announced in April 2010 to reduce greenhouse gas emissions from new cars and light trucks. Finally, a number of voluntary programs have been continued and proposed to aid other organizations in measuring and reducing greenhouse gas emissions.

The Obama Administration's agenda and strong actions taken at the US EPA are thought to have spurred Congress into drafting comprehensive energy and climate policy (see discussion below). While the US EPA has the authority to regulate greenhouse gas emissions using traditional 'command and control' regulatory methods, many think this method is inadequate to effectively address the complexity of climate change. Additionally, US EPA regulation does not provide incentives and mandates to transition the USA away from fossil fuels and towards clean energy or for adaptation planning. Additionally, the US EPA is not equipped to address higher consumer costs of electricity and fuels or the potential loss of industry to developing countries. According to a recent study, a consensus (that is, 91.6 percent) among economic experts is that market-based mechanisms such as a carbon tax or cap and trade program is the 'preferred or strongly preferred' approach over traditional regulation to reduce greenhouse gas emissions and that significant risks to specific sectors in the USA and abroad exists if emissions are not reduced (Holladay, Jonathan, \& Swchwarz 2009). It appears that neither the Presidential Administration nor any one Federal Agency (for example, the US EPA or the US DOE) is fully equipped to implement a market-based system. This approach, or a carbon tax, are more suited to be legislated through congressional action. Therefore, greenhouse gas litigation, Presidential action, and US EPA action have effectively moved Congress to move beyond debate and begin to take action to enact legislation to reduce greenhouse gas emissions.

\section{Congressional national climate policy (legislative branch)}

While a national climate policy was introduced in former Congresses prior to the Obama administration, these bills have not progressed in any significant manner. However, due to actions taken by the courts, President Obama's initiatives, a democratdominated Congress, and new US EPA regulations, the $111^{\text {th }}$ Congress had initiated 
significant action. In the summer of 2009, the American Clean Energy and Security Act of 2009 (referred to as the Waxman-Markey bill) narrowly passed the US House of Representatives with a vote of 219-212 (Congressmen Waxman and Markey 2009). Following the passage of the Waxman-Markey bill, a similar bill was advanced in the Senate, titled Clean Energy Jobs and American Power Act (referred to as the KerryBoxer bill) and passed the Environmental and Public Works committee on November 5, 2009 (Senators Kerry and Boxer 2009). The senate bill initially showed promise of reaching the Senate floor and ultimately being sent to the President for ratification; however, the bill stalled. Additional bills were brought forth later in the $111^{\text {th }}$ Congress. However, at the close of the Congressional section, no Senate bill was passed leaving the passage of federal climate policy up to the incoming $112^{\text {th }}$ Congress.

The shift to GOP leadership in $112^{\text {th }}$ Congress has not only ceased the possibility of enacting a federal climate bill, but has resulted in the reverse, namely threats to delay or outright repeal the US EPA authority to regulate greenhouse gases under the Clean Air Act (Koch 2011). The bill with the most momentum is The Energy Tax Prevention Act of 2011 (also known as the Upton bill), which would not only remove the US EPA's authority to regulate greenhouse gases, but would also repeal the endangerment finding (Upton 2011). The Upton bill, with 46 co-sponsors most of which are Republican, passed the House subcommittee on March 11, 2011 and is scheduled for debate in the full House Energy and Commerce Committee in March 2011 (Koch 2011). US EPA Administrator Lisa Jackson testified to the subcommittee on March 11, 2011 that the Upton bill would 'overrule the scientific community on the scientific finding that carbon pollution endangers Americans' health and well being' (Jackson 2011). The bill passed the House on April 7, 2011 and was referred to the Senate the next day where it was read twice and referred to the Committee on Environment and Public Works. If the Senate passes this bill, this legislation would stop regulatory initiatives in progress at the US EPA and would likely be sent back to the courts for further hearings.

While neither the Waxman-Markey nor the Kerry-Boxer bills were ultimately ratified, it is worthwhile to evaluate the provisions contained in the bills as they provide a framework for federal climate policy. In addition, these bills will likely provide the foundation for the next climate bill submitted in the next Congress. Both the WaxmanMarkey and Kerry-Boxer bills were strikingly similar and both have the same stated 
purpose, which is, 'to create clean energy jobs, achieve energy independence, reduce global warming pollution, and transition to a clean energy economy.' It is important to note that the Waxman-Markey Bill is 1,498 pages in length, and the Kerry-Boxer bill that passed the Environment and Public Works Committee totals 821 pages; therefore, a comprehensive analysis of both bills is limited in this article and the reader should refer to the original bills for more detail (Senators Kerry \& Boxer 2009; Congressmen Waxman \& Markey 2009).

The remainder of this section provides a summary of both bills and is organized by the four major titles of the Waxman Markey bill, namely clean energy, energy efficiency, global warming reduction (cap and trade program), and the clean energy transition plan. Each section contains a summary table of the major provisions followed by a discussion of key provisions from Waxman-Markey. Where different, the Kerry-Boxer bill provisions are also discussed.

\section{Clean energy (Title I)}

Since consumption of fossil fuel energy represents the majority of greenhouse gas emission sources in the United States, transitioning to clean energy sources would significantly reduce greenhouse gas emissions. Both the Waxman-Markey and KerryBoxer bills include policies and programs designed to promote the development and rapid deployment of clean energy. Table 1 provides a summary of the key clean energy provisions of the Waxman-Markey bill:

\begin{tabular}{|c|c|}
\hline \multicolumn{2}{|c|}{ Key Provisions } \\
\hline 0 & Establishes a nationwide Combined Efficiency and Renewable Electricity Standard (CERES) \\
\hline & $\begin{array}{l}\text { o Establishes the supply targets (6\% supply in } 2012 \text { and is gradually increased to } 20 \% \\
\text { in 2039) }\end{array}$ \\
\hline & $\begin{array}{l}\text { o Establishes the breakdown of supply (3/4 from renewable energy and } 1 / 4 \text { supply from } \\
\text { energy efficiency) }\end{array}$ \\
\hline & Establishes a Federal Renewable Energy Credit (REC) program \\
\hline 0 & $\begin{array}{l}\text { Spurs R\&D and the rapid commercialization of carbon capture and storage (CCS) from the } \\
\text { combustion of coal }\end{array}$ \\
\hline 0 & Incentivizes the transition to the large-scale electrification of vehicles \\
\hline 0 & Establishes state accounts to distribute emission allowances to be used to fund energy projects \\
\hline 0 & $\begin{array}{l}\text { Improves the distribution of clean energy with Smart Grid technology and transmission } \\
\text { planning }\end{array}$ \\
\hline 0 & $\begin{array}{l}\text { Establishes and funds research, education, and training facilities (i.e., Energy Innovation Hubs } \\
\text { and Centers for Energy and Environmental Knowledge and Outreach) }\end{array}$ \\
\hline 0 & Establishes revolving loans to fund research of advanced technologies as well as nuclear \\
\hline & Requires miscellaneous studies, determinations, and new agency development \\
\hline
\end{tabular}

Table 1. Clean Energy (Title I) Key Provisions in the Waxman-Markey bill 
Notably, the Waxman-Markey bill specifies a nationwide Combined Efficiency and Renewable Electricity Standard (CERES) — this is also referred to as a national renewable portfolio standard (RPS). The Kerry-Boxer bill differs in that it does not designate a national standard, but rather provides incentives to states that have adopted an RPS. A national standard would create uniform goals across the nation. Currently, 33 states have voluntary or binding RPS programs in place and the targets differ significantly (US Department of Energy Energy Efficiency \& Renewable Energy 2010). While the Senate version would encourage more states to develop an RPS, a nationwide system would be a more comprehensive approach and would require that all states participate, thus creating equitable solutions in transitioning towards clean energy in the country.

Both bills are full of provisions to improve our current electricity production in this country, particularly coal. For example, both bills will require coal-fired power plants to meet performance standards with targets of 65 percent greenhouse gas reduction for plants permitted after 2020. The bills also provide for significant research to advance carbon capture and sequestration technology. Both bills have provisions to increase electrical capacity, including the large-scale electrification of vehicles, Smart Grid, and Transmission Technology. The Waxman-Markey bill only briefly mentions nuclear energy under the heading of 'Advanced Technology,' while the Kerry-Boxer bill included more provisions for the nuclear industry, including additional training for the nuclear workforce and research and development for nuclear facilities.

\section{Energy efficiency (Title II)}

Both bills provide for policies whose goals are to improve energy efficiency in the built environment as well as to improve transportation efficiencies. Table 2 provides a summary of the key provisions contained in Title II of the Waxman-Markey bill. As stated in Table 2, the Waxman-Markey bill stipulates an initial 30 percent improvement of energy efficiency in buildings with an ultimate goal of achieving 'zero-net-energy' consumption. The bill proposes to achieve these goals through the development of stringent building standards and incentives. The Kerry-Boxer bill differs in that it does not specify energy efficiency targets, but rather assigns that responsibility to the US EPA administrator to establish beginning in the year 2014. The Waxman-Markey bill is far more aggressive with immediate targets and an ultimate goal of zero energy 
consumption. In addition, the Waxman-Markey bill contains a national energy efficiency goal that stipulates an overall 2.5 percent improvement by 2012, a provision that is absent in the Kerry-Boxer bill.

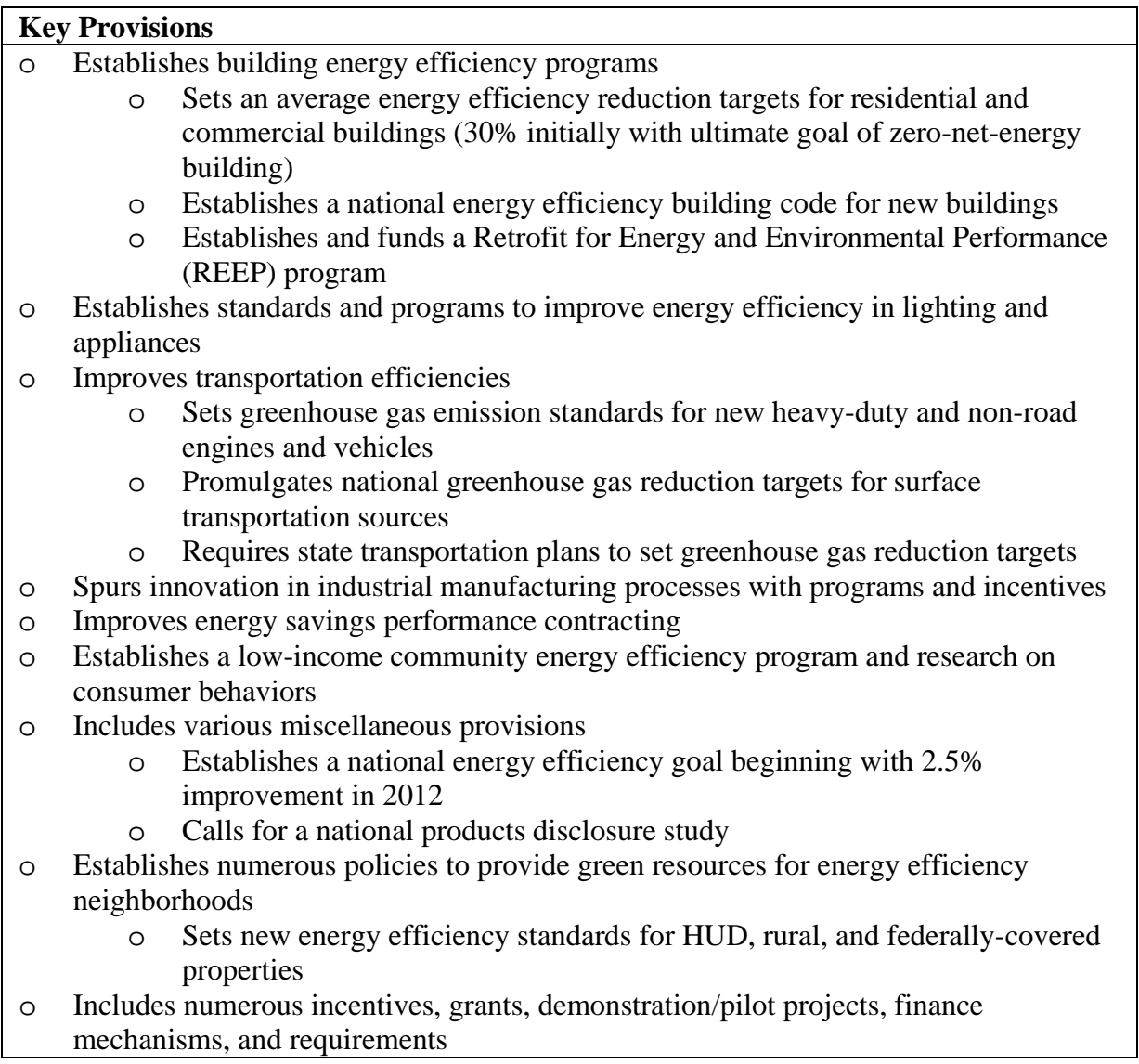

Table 2. Energy Efficiency (Title II) Key Provisions in the Waxman-Markey bill

The Waxman-Markey bill would require that greenhouse gas emissions standards be set for new heavy-duty and off-road engines and vehicles within three model years commencing four years after bill enactment, a provision that is absent in the KerryBoxer bill. However, both bills will require that national transportation greenhouse gas reduction goals be established within 18 months of enactment of the bill. Lastly, both bills contain a number of other incentive programs as well as investment in research, technology advancement, and education.

\section{Reducing global warming pollution (Titles III and V)}

The third title establishes a national Cap and Trade Program that includes greenhouse gas emission reduction targets and flexible compliance mechanisms for covered entities. 
Title V addresses carbon offset projects related to forestry and agriculture and has been included in this section because offsets are one of the flexible mechanisms included in the Cap and Trade Program. Table 3 provides a summary of the key provisions contained in Titles III and V of the Waxman-Markey bill.

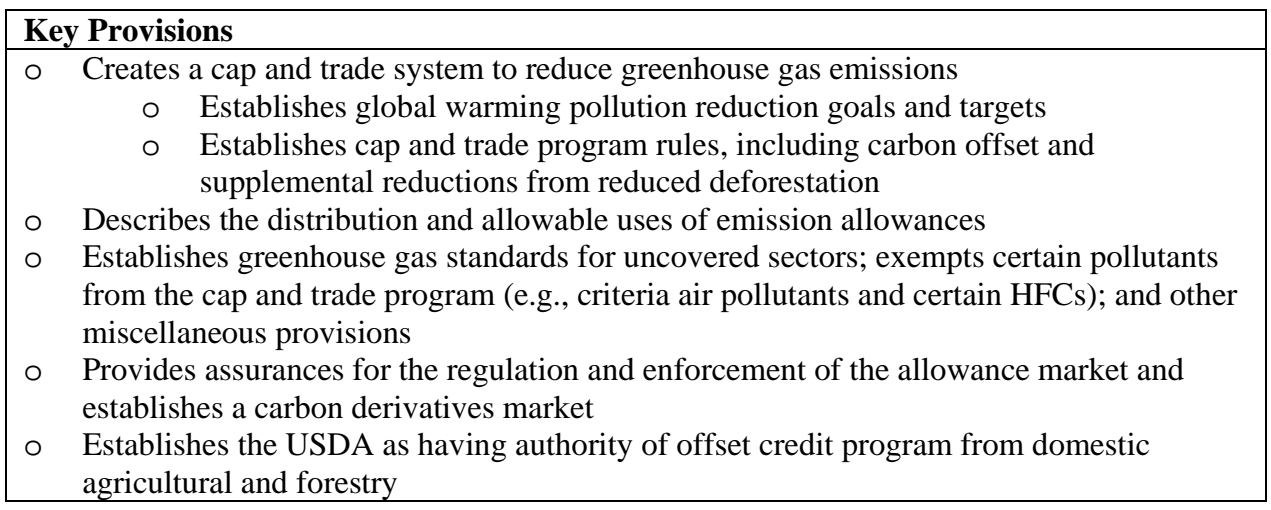

Table 3. Cap and Trade (Titles III and V) Key Provisions in the Waxman-Markey bill

For both bills, the greenhouse gas reduction target begins at 3 percent of 2005 levels by 2012 and then is ratcheted up to 83 percent by 2050. The Kerry-Boxer bill has the same beginning and end targets, but has different interim targets. Both bills allow two billion carbon offsets to meet the overall reduction target; however, Waxman-Markey allows for one billion carbon offsets originating from international projects whilst Kerry-Boxer limits offsets to one-half billion. Both bills lay out detailed rules for the implementation of a cap and trade program including how allowances will be distributed and how the program and markets will be regulated and enforced. An important provision in both bills dictates how revenue generated from the sale or distribution of emission allowances must be passed through to the consumer to offset the higher cost of energy. This provision will help alleviate hardship to those that are most affected by higher electricity costs, specifically low-income residential consumers. Standards and rules will be promulgated to regulate greenhouse gases in non-covered sectors, which would include greenhouse gas sources that fall below the threshold and sectors that have the potential to enhance carbon sequestration, such as forestry and agriculture. Both bills outline how the cap and trade program will be strictly monitored to ensure real and additional greenhouse gas emission reductions. Additionally, significant portions of generated funds from the program will be directed to various incentive programs, adaptation programs, research, and education. 


\section{Clean energy transition plan (Title IV)}

Title IV outlines a transition plan that would move America towards a clean energy economy. Table 4 provides a summary of the key provisions contained in Titles IV of the Waxman-Markey bill:

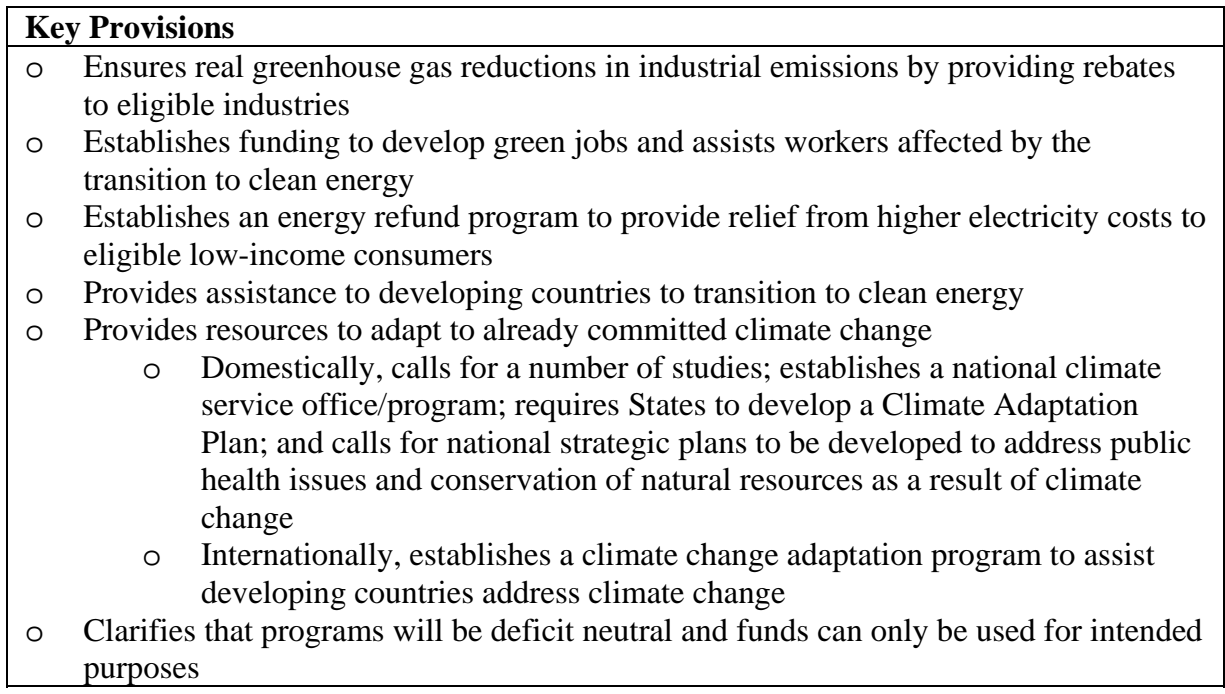

Table 4. Transition Plan (Title IV) Key Provisions in the Waxman-Markey bill

The Waxman-Markey bill contains rebates to American industry to ensure that they remain competitive in the global markets and that industry 'leakage' does not occur (that is, industry is not exported overseas). In addition to standard rebates for all consumers dictated in Title III, additional energy refunds will be given to low-income residents and specific industries that will be the hardest hit from increased energy costs.

Both bills establish programs to train workers to enter the green workforce and help workers that might lose their jobs as a result of the transition. The bill also provides assistance to developing countries to facilitate the transition to clean energy. Lastly, both bills have significant provisions to prepare for domestic and international adaptation that require state plans that not only address the direct impacts from climate change, but also address public health and natural resources.

\section{Discussion and conclusions}

The use of the court systems to attempt to change environmental policy is not new. Until recently, the lack of leadership in the executive and legislative bodies in solving the problems associated with climate change left little recourse but the courts for those 
concerned with the impact of global warming. Several court cases, particularly Massachusetts v US EPA, forced the government to address climate change within the executive branch through US EPA regulation. The legislative branch has been slower to act. The $111^{\text {th }}$ Congress acted largely due to the pressures from the executive branch and the outcome of judicial court cases, while the $112^{\text {th }}$ Congress is acting to uses its regulatory power to attempt to repeal both executive and judicial action.

Clearly, the fate of national climate legislation is unclear at best. 'Institutional gridlock' appears to be the roadblock that may thwart federal legislative action on climate change (Byrne et al. 2007). In short, it is usually easier to prevent legislation than it is to pass it. In the $111^{\text {th }}$ Congress, this gridlock, along with the untimely loss of the democratic super-majority (from the replacement of Senator Kennedy's seat), a troubled economy, and an exhaustive healthcare debate very likely prevented legislative action from occurring. And now, the GOP-led $112^{\text {th }}$ Congress is using the economy as a major argument to pass legislation to stop regulation of greenhouse gases altogether (Koch 2011).

Yet, the national climate change policy passed in the House of Representatives (Waxman-Markey bill) and proposed in the Senate (Kerry-Boxer bill) provides a comprehensive approach to reduce greenhouse gas emissions, improve energy efficiency, provide incentives to develop clean energy, and plan for the transition to a clean energy economy. This national climate policy includes clear greenhouse gas reduction targets with a timeline and provides for flexible compliance mechanisms for covered sectors to comply with the proposed legislation. Economists nearly all agree that a national climate policy that utilizes cap and trade is the lowest-cost approach to reducing greenhouse gas emissions in the United States (Chettiar \& Schwartz 2009). Cap and trade programs for other pollutants (for example, acid rain) have been shown to be an effective and fair approach to address the problem. Additionally, cap and trade programs can be implemented at relatively lower costs than traditional 'command and control' regulations because covered sectors can select the most cost effective solution to meet its compliance target. However, some economists favor a carbon tax because they believe that a carbon tax would be simpler and quicker to implement (Avi-Yonah \& Ulmann 2009). Regardless of the approach, neither market-based policy instruments are anywhere near implementation through legislative means, and neither approach is 
being considered by the US EPA under the current Clean Air Act initiatives.

As discussed above, the President has issued Executive Orders to reduce greenhouse gas emissions within federal agencies. He could exercise the same power to set greenhouse gas reduction targets that are within the jurisdiction of the executive branch. Past presidents have often used this power to enact policy and strengthen their administrative powers (Mayer 1999). However, the authority to implement such a comprehensive policy would be limited to the executive branch and would likely be challenged for its constitutionality and statutory authority in the courts.

Neither the courts nor the President have the ability or clear authority to implement a comprehensive cap and trade program that includes incentives for clean energy and a plan to transition American toward a carbon constrained economy that congressional legislation outlined in its bills. In the absence of such legislation, the US EPA has set into motion significant and binding regulation of greenhouse gases. Since legislation was not enacted, the US EPA regulation is the only real US greenhouse gas policy and is in danger of being stopped in its tracks if the GOP is successful with legislation (i.e., if the Upton Bill passes in the Senate). While the legislative and executive branches are the best places to resolve political national issues like management of greenhouse gases and associated climate change, the courts have as of late been one way to influence greenhouse gas policy. Massachusetts et al. v. US EPA directly resulted in the development of the Endangerment Finding and the pending regulations of greenhouse gas emissions by the US EPA. The lack of a clear legislative greenhouse gas policy weakens the US EPA's regulatory authority and puts many issues such as transitioning to clean energy and implementing a cap and trade program in limbo, particularly given the recent congressional effort to limit EPA's authority over greenhouse gas emissions.

Even in light of the conclusion that greenhouse gases may be regulated regardless of Congressional action, detractors of any national climate policy remain focused on continuing the debate on whether climate change is real thereby attempting to delay meaningful national policy. For example, a recent controversy, referred to as 'ClimateGate,' whereby a set of emails and files that apparently point out flaws in a small set of climate-change research has been used by advocates of climate policy to cast doubt with the US public (Fahrenthold \& Eilperin 2009), even though US government scientists and the rest of the climate community say that the emails/files do nothing to negate the 
overwhelming conclusion that global climate change is real.

Hopefully, the US public and Congressional policymakers can move beyond this debate and if nothing else understand that time is not a luxury that we can afford and that the window of opportunity to mitigate climate change in a cost-effective manner may be closing (Holladay et al. 2009).

\section{Reference List}

Armitage, K. C. 2005, 'The United States and the Politics of Global Warming,' Globalization, vol. 2, no. 3, 417-427.

Arnold \& Porter, LLP 2011, Climate Change Litigation in the US. Online, available: http://www.climatecasechart.com [Accessed 11 March 2011].

Austin, D., \& Dinan, T. 2005, 'Clearing the Air: The Costs and Consequences of Higher CAFE Standards and Increased Gasoline Taxes,' Journal of Environmental Economics and Management, vol. 50, no. 3, 562-582.

Avi-Yonah, R. S., \& Ulmann, D. M. 2009, 'Combating Global Climate Change: Why a Carbon Tax is Better Response to Global Warming than Cap and Trade,' Stanford Environmental Law Journal, vol. 28, no. 3:1-49.

Byrne, J., Hughes, K., Rickerson, W., \& Kurdgelashvili, L. 2007, 'American Policy Conflict in the Greenhouse: Divergent Trends in Federal, Regional, State, and Local Green Energy and Climate Change Policy,' Energy Policy, vol. 35, no. 9, 4555-4573.

Carpenter, C. 2001, 'Business, Green Groups and the Media: The Role of NonGovernmental Organizations in the Climate Change Debate,' International Affairs, vol. 77, no. 2, 313-328.

Cayan, D. R., Luers, A. L., Franco, G., Hanemann, M., Croes, B., \& Vine, E. 2008, 'Overview of the California Climate Change Scenarios Project,' Climate Change, no. 87, Suppl. 1, S1-S6.

Chettiar, I. M., \& Schwartz, J. A. 2009, The Road Ahead: EPA’s Options and Obligations for Regulating Greenhouse Gases, Report No. 3. Institute for Policy Integrity, New York University School of Law, New York.

Congressmen Waxman \& Markey 2009, American Clean Energy and Security Act of 2009 (Engrossed as Agreed to or Passed by House). Online, available: http://thomas.loc.gov/cgi-bin/query/z?c111:H.R.2454.EH: [Accessed 9 Dec. 2009].

Council on Environmental Quality 2009, President Obama signs an Executive Order Focused on Federal Leadership in Environmental, Energy, and Economic Performance, Press Release. Online, available: <http://www.whitehouse.gov/the_press_office/President-Obama-signs-anExecutive-Order-Focused-on-Federal-Leadership-in-Environmental-Energyand-Economic-Performance [Accessed 5 Dec. 2009].

Craig, R. K. 2009, 'The Clean Water Act on the Cutting Edge: Climate Change and Water Quality Regulation,' Natural Resources and the Environment, vol. 24, no. 2,14 . 
Fahrenthold, D. A., \& Eilperin, J. 2009. 'In E-mails, Science of Warming is Hot Debate: Stolen files of "Climate-gate" Suggest some Viewpoints on Change are Disregarded.' The Washington Post, December 5

Federal Register 2009, Ocean Acidification and Marine pH Water Quality Criteria, Environmental Protection Agency, EPA-HQ-OW-2009-0224; FRL-8892-5, vol.74, no. 71, April 15, 2009, Notices.

Freidman, T. L. 2005, The World is Flat: A Brief History of the Twenty-First Century. Farrar, Straus and Giroux, New York.

Gerrard, M. B. 2007, Global Climate Change and US Law. American Bar Association, Chicago.

Grynbaum, M. M. 2011. 'Supreme Court Halts Mayor’s Push for Hybrid Taxis.' The New York Times, March 13.

Hays, G. C., Richardson, A. J., \& Robinson, C. 2005, 'Climate Change and Marine Plankton,' Trends in Ecology and Evolution, vol. 20, no. 6, 337-344.

Hoegh-Guldberg, O. H., Mumby, P. J., Hooten, A. J., Steneck, R. S., P., G., Gomez, E., Harvell, C. D., Sale, P. F., Edwards, A. J., Caldeira, K., Knowlton, N., Eakin, C. M., Iglesias-Prieto, R., Muthiga, N., Bradbury, R. H., Dubi, A., \& Hatziolos, M. E. 2007, 'Coral Reefs Under Rapid Climate Change and Ocean Acidification,' Science, vol. 318, no. 5857, 1737-1742.

Holladay, J. S., Jonathan, H., \& Swchwarz, J. A. 2009, Economists and Climate Change: Consensus and Open Questions, Policy Brief No. 5. Institute for Policy Integrity, New York University School of Law, New York.

IPCC 1992, Climate Change 1992: The Supplementary Report to the IPCC Scientific Assessment, (eds) Houghton, J. T., and the Core Writing Team, B. A. Callander \& S. K. Varney. Cambridge University Press, Cambridge \& New York. 1995, IPPC Second Assessment - Synthesis of Scientific-Technical Information Relevant to Interpreting Article 2 of the UN Framework Convention on Climate Change: Cambridge Univesity Press, Cambridge \& New York.

2001, Climate Change 2001: Synthesis Report. A Contribution of Working Groups I, II, and III to the Third Assessment Report of the Intergovernmental Panel on Climate Change, (eds) R. T. Watson. and the Core Writing Team. Cambridge University Press, Cambridge \& New York. 2007a, Climate Change 2007: Synthesis Report, (eds) A. Allali, R. Bojariu, S. Diaz, I. Elgizouli, D. Griggs, D. Hawkins, O. Hohmeyer, B. Pateh, L. KajifexBogataj, N. Leary, H. Lee \& D. Wratt. IPCC, Geneva, Switzerland. 2007b, Climate Change 2007: Synthesis Report. Contributions of the Working Groups I, II and III to the Fourth Assessment Report of the Intergovernmental Panel on Climate Change, Core Writing Team, R. K. Pachauri and G. Reisinger. IPCC, Geneva, Switzerland.

Jackson, L. 2011, Administrator Lisa P. Jackson, Testimony Before the US House Subcommittees on Energy and Power and Environment and Economy. US EPA News Releases, 11 March.

Koch, W. 2011, GOP House Moves to Stop EPA Climate Rules. USA Today, 11 March.

Labatt, S., \& White, R. R. 2007, Carbon Finance: The Financial Implications of Climate Change. John Wiley and Sons, Hoboken, NJ.

Leiserowitz, A. 2006, 'Climate Change Risk Perspective and Policy Preferences: The Role of Affect, Imagery, and Values,' Climate Change, vol. 77, no. 1, 45-72.

Lutsey, N., \& Sperling, D. 2005, 'Energy Efficiency, Fuel Economy, and Policy Implications,' Transportation Research Record: Journal of the Transportation Research Board, no. 1941, 8-17. 
Mayer, K. R. 1999, 'Executive Orders and Presidential Power,' The Journal of Politics, vol. 61, no. 2, 445-466.

McCarl, B. A., \& Schnieder, U. A. 2000, 'U.S. Agriculture’s Role in a Greenhouse Gas Emission Mitigation World: An Economic Perspective,' Review of Agricultural Economics, vol. 22, no. 1, 134-159.

McCright, A. M., \& Dunlap, R. E. 2003, 'Defeating Kyoto: The Conservative Movement's Impact on US Climate Change Policy,' Social Problems, vol. 50, no. 3, 348-373.

Office of the President Elect 2008, President-elect Barack Obama Announces Key Members of Energy and Environment Team - Press Release. Online, available: $\leq$ http://change.gov/newsroom/entry/president_elect_barack_obama_announces key_members_of_energy_and_environmen/> [Accessed 5 Dec. 2009].

Organization for Economic Co-Operation and Development 1992, The Polluter-Pays Principle, OECD Analysis and Recommendations. Online, available: http://www.oecd.org/officialdocuments/publicdisplaydocumentpdf/?cote=OCDE /GD(92)81\&docLanguage=En [Accessed 10 March 2011].

Organizing for America 2009, Organizing on the Issues, Energy and Environment. Online, available: http://www.barackobama.com/issues/newenergy/index.php [Accessed 7 Dec. 2009].

Patz, J. A., Campbell-Lendrum, D., Holloway, T., \& Foley, J. A. 2005, 'Impact of Regional Climate Change on Human Health,' Nature, vol. 438, 310-317.

Rose, A., \& Oladosu, G. 2002, 'Greenhouse Gas Reduction Policy in the United States: Identifying Winners and Losers,' The Energy Journal 23:1-18.

Rowe, D. 2007, 'Education for a Sustainable Future,' Science, vol. 317, no. 5836, 323324.

Samuelsohn, D. 2009, 'Obama Negotiates “Copenhagen Accord” With Senate Climate Fight in Mind.' The New York Times, 21 December.

Schreurs, M. A. 2008, 'From the Bottom Up: Local and Subnational Climate Change Politics,' The Journal of Environmental and Development, vol. 17, no. 4, 343355.

Senators Kerry \& Boxer 2009, Clean Energy Jobs and American Power Act (Introduced in Senate September 30). Online, available: http://thomas.loc.gov/cgibin/query/z?c111:S.1733: [Accessed 7 Dec. 2009].

Sheppard K. 2012, 'Can the US Live up to Its Climate Pledge,' Mother Jones, 7 December. Online, available: http://motherjones.com/blue-marble/2011/12/canus-live-its-climate-pledge [Accessed 7 Dec. 2012].

Superior Court of Fulton County, G. 2008, Friends of the Chattahoochee, Inc. and Sierra Club v. Dr. Carol Couch and Longleaf Energy Associates, No. 2008 CV146398.

Supreme Court of South Dakota 2008, In the Matter of Otter Tail Power Company on Behalf of Big Stone II Co-Owners for an Energy Conversion Facility Permit for the Construction of the Big Stone II Project, \#24485.

US Court of Appeals for the Second Circuit 2005, State of Connecticut, et. al. v. American Electric Power Company Inc., et. al, 05-5104-cv, 05-5119-cv.

US Department of Energy Energy Efficiency \& Renewable Energy 2010, States with Renewable Portfolio Standards. Online, available: http://apps1.eere.energy.gov/states/maps/renewable_portfolio_states.cfm. [Accessed 10 March 2011].

US Environmental Protection Agency 2010, Integrated Reporting and Listing Decisions Related to Ocean Acidification. Online, available: 
http://water.epa.gov/lawsregs/lawsguidance/cwa/tmdl/upload/oa_memo_nov201 0.pdf [Accessed 10 March 2011].

United Nations Framework Convention on Climate Change 2009, Copenhagen Accord, Draft Decision -/CP.15. Online, available: http://unfccc.int/resource/docs/2009/cop15/eng/107.pdf [Accessed 25 Jan. 2009].

United States Court of Appeals for the Fifth Circuit 2009, Ned Comer, et al. v. Murphy Oil USA, et al., No. 07-60756.

United States Department of Energy Energy Efficiency \& Renewable Energy 2010, States with Renewable Portfolio Standards. Online, available: http://apps1.eere.energy.gov/states/maps/renewable portfolio states.cfm [Accessed 12 Dec. 2009].

United States District Court for the District of Oregon 2006, Northwest Envinmental Defense Center et al. v. Owens Corning, Civil No. 04-1727-JE.

United States District Court for the Eastern District of California 2008, Central Valley Chrysler Jeep, Inc. et al. v. Goldstene, No. CV F 04-6663 AWI LJO.

United States District Court for the Northern District of California 2007a, Center for Biological Diversity et al. v. Dirk Kepthorne, Secretary of the Interior et al. No. C-07-0894-EDL. 2007b, Center for Biological Diversity, et al. v. Dr. William Brennan et al., Oakland Division, No. C-06-7062 SBA.

2008, Center for Biological Diversity, et al. v. Office of Management and Budget, No. C 07-04997 MHP. 2009, Native Village of Kivalina and City of Kivalina v. Exxon Mobil Corporation et al., San Francisco Division, No. 08-CV-1138.

United States District Court for the Southern District of New York 2005, Korsinksy v. United States Environmental Protection Agency, No. 05 Civ. 859 (NRB).

United States Environmental Protection Agency 2009, Climate Change - Regulatory Initiatives. Online, available: http://www.epa.gov/climatechange/initiatives/index.html [Accessed 16 Dec. 2009].

_ 2009, Letter to Ms. Miyoka Sakashita, Attorney, Center for Biological Diversity, dated January 16, 2009.

United States Supreme Court 2006, Massachusetts et al. v. Environmental Protection Agency et al. at 1459-63.

United States Supreme Court for the Southern District of New York 2005, State of Connecticut et al. v. American Power Company, Inc. et al., No. 04-Civ. 5669 (LAP), 04 Civ. 5670 (LAP).

Upton, F. 2011, Energy Tax Prevention Act of 2011, H.R. 910, House of Representatives.

Yudelson, J., \& Fedrizzi, S. R. 2008, The Green Building Revolution. Island Press, Washington, DC. 